\title{
Cytotoxic Activity of Extracts from Plants of Central Argentina on Sensitive and Multidrug-Resistant Leukemia Cells: Isolation of an Active Principle from Gaillardia megapotamica
}

\author{
María Laura González, ${ }^{1}$ Mariana Belén Joray, ${ }^{1}$ Jerónimo Laiolo, ${ }^{1}$ María Inés Crespo, ${ }^{1}$ \\ Sara María Palacios, ${ }^{1}$ Gustavo Miguel Ruiz, ${ }^{2}$ and María Cecilia Carpinella $\mathbb{D}^{1}$ \\ ${ }^{1}$ Fine Chemical and Natural Products Laboratory, School of Chemistry, IRNASUS-CONICET, Catholic University of Córdoba, \\ Avda. Armada Argentina 3555, X5016DHK Córdoba, Argentina \\ ${ }^{2}$ Herbarium Marcelino Sayago, School of Agricultural Science, Catholic University of Córdoba, \\ Avda. Armada Argentina 3555, X5016DHK Córdoba, Argentina
}

Correspondence should be addressed to María Cecilia Carpinella; ceciliacarpinella@ucc.edu.ar

Received 12 October 2017; Revised 20 February 2018; Accepted 26 March 2018; Published 10 May 2018

Academic Editor: Yoshiyuki Kimura

Copyright (C) 2018 María Laura González et al. This is an open access article distributed under the Creative Commons Attribution License, which permits unrestricted use, distribution, and reproduction in any medium, provided the original work is properly cited.

\begin{abstract}
Plants are a significant reservoir of cytotoxic agents, including compounds with the ability to interfere with multidrug-resistant (MDR) cells. With the aim of finding promising candidates for chemotherapy, 91 native and naturalized plants collected from the central region of Argentina were screened for their cytotoxic effect toward sensitive and MDR P-glycoprotein (P-gp) overexpressing human leukemia cells by means of MTT assays. The ethanol extracts obtained from Aldama tucumanensis, Ambrosia elatior, Baccharis artemisioides, Baccharis coridifolia, Dimerostemma aspilioides, Gaillardia megapotamica, and Vernonanthura nudiflora presented outstanding antiproliferative activity at $50 \mu \mathrm{g} / \mathrm{mL}$, with inhibitory values from 93 to $100 \%$, when tested on the acute lymphoblastic leukemia (ALL) cell line CCRF-CEM and the resistant derivative CEM-ADR5000, while 70-90\% inhibition was observed against the chronic myelogenous leukemia (CML) cell K562 and its corresponding resistant subline, Lucena 1. Subsequent investigation showed these extracts to possess marked cytotoxicity with $\mathrm{IC}_{50}$ values ranging from 0.37 to $29.44 \mu \mathrm{g} / \mathrm{mL}$, with most of them being below $7 \mu \mathrm{g} / \mathrm{mL}$ and with ALL cells, including the drug-resistant phenotype, being the most affected. G. megapotamica extract found to be one of the most effective and bioguided fractionation yielded helenalin (1). The sesquiterpene lactone displayed $\mathrm{IC}_{50}$ values of $0.63,0.19,0.74$, and $0.16 \mu \mathrm{g} / \mathrm{mL}$ against K562, CCRF-CEM, Lucena 1, and CEM/ADR5000, respectively. These results support the potential of these extracts as a source of compounds for treating sensitive and multidrug-resistant leukemia cells and support compound $\mathbf{1}$ as a lead for developing effective anticancer agents.
\end{abstract}

\section{Introduction}

Leukemia is a malignant disorder with a significant number of deaths annually [1]. According to GLOBOCAN, about 352,000 new cases of leukemia and 265,000 deaths occurred worldwide in 2012 [2].

Despite overall improvement in the outcome of conventional leukemia therapies $[3,4]$, some patients have poor survival rates [5] or suffer from side effects of the drugs administered [3, 4, 6], and relapse is often observed [7]. In addition, a major problem in the treatment of leukemia is the development of resistance to chemotherapeutic agents. Many cancers, including leukemia, are resistant to a wide array of chemically and functionally unrelated agents, a phenomenon known as multidrug resistance (MDR).

Various mechanisms underlie this type of resistance, the most common being overexpression of the P-glycoprotein (Pgp) transporter (ABCB1/MDR1) [8]. This protein, located in the cell membranes, is involved in the traffic of chemotherapeutic drugs outside the cancer cell [6] or in the sequestration of these in cytoplasmic organelles, preventing their therapeutic effect [9]. More than a third of cells from patients with 
leukemia were positive to P-gp [10]. High levels of this pump were detected in about $50 \%$ of patients with chronic myelogenous leukemia (CML) unresponsive to chemotherapy [11], while 12 and $29 \%$ of patients with acute myeloid leukemia (AML) showed high and intermediate P-gp expression, respectively [12]. For these reasons, academy and industry still concentrate on finding promising candidates for an effective and safe therapy for leukemia.

A considerable number of plants have been recognized with rich potential as a therapeutic resource, and many of their derived molecules were active on leukemia cells, including resistant phenotypes [6]. Many compounds with medicinal properties have been obtained from flora from Argentina $[8,13-16]$, but this resource is far from being completely explored.

The present work reports antiproliferative activity on sensitive and P-gp overexpressing leukemia cell lines of a panel of 91 extracts obtained from native and naturalized plants of Central Argentina. One of the most potent extracts, Gaillardia megapotamica, was submitted to bioguided fractionation to further isolate the active principle responsible for its cytotoxicity.

\section{Materials and Methods}

2.1. Plant Material and Extract Preparation. Plants were collected in the hills of Córdoba Province, Argentina, from November to March 2016-2017. Voucher specimens have been deposited in the "Marcelino Sayago" Herbarium of the School of Agricultural Science, Catholic University of Córdoba, and were authenticated by the botanist, G. Ruiz. Plants were selected according to their availability, accessibility, and especially the lack of scientific information about their activity and/or chemical pattern. Crushed, air-dried material (200 g) was extracted by $48 \mathrm{~h}$ maceration with $700 \mathrm{~mL}$ of $96 \%$ ethanol. The yields of each active extract, obtained after exhaustive solvent removal and expressed as percentage weight of air-dried crushed plant material, are shown in Table 2. The phytochemical profiles of the active extracts were obtained by HPLC (see supplementary material (available here)). Extract solutions were prepared immediately prior to testing.

2.2. Chemicals, Equipment, and Reagents. 3-(4,5-Dimethyl2-thiazolyl)-2,5-diphenyl-2H-tetrazolium bromide (MTT) and lectin from Phaseolus vulgaris (PHA) were purchased from Sigma Aldrich, (Sigma-Aldrich Co., St Louis, MO). Doxorubicin hydrochloride (DOX, 99.8\%, Synbias Pharma Ltd.) was obtained from Nanox Release Technology (Buenos Aires, Argentina) and was used dissolved in bidistilled water. RPMI-1640 and cell culture reagents $\mathrm{Gibco}^{\circledR}$ were purchased from Invitrogen Life Technologies (Carlsbad, CA). Sterile plastic material was purchased from Greiner Bio-One (Frickenhausen, Germany). All solvents were HPLC grade. ${ }^{1} \mathrm{H}$ - and ${ }^{13} \mathrm{C}$-NMR and two-dimensional spectra were recorded with a Bruker AVANCE II 400 spectrometer (Bruker Corporation, Ettlingen, Germany) with tetramethylsilane (TMS) as the internal reference. HPLC was performed on a Shimadzu LC-10 AS (Shimadzu Corp., Tokyo, Japan), equipped with a Luna C18, $250 \times 4.6 \mathrm{~mm}$ reversed-phase column. The mobile

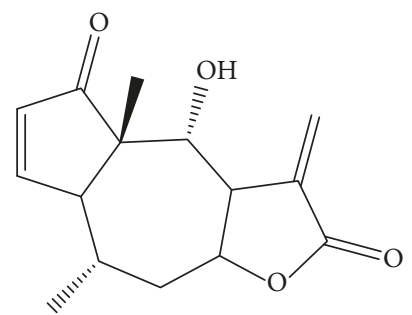

FIgURE 1: Chemical structure of helenalin (1).

phases were $\mathrm{ACN} / \mathrm{H}_{2} \mathrm{O} 30: 70, \mathrm{ACN} / \mathrm{H}_{2} \mathrm{O} 10: 90$, and $\mathrm{ACN} /$ $\mathrm{H}_{2} \mathrm{O} 70: 30$ with UV detection at 210 and $280 \mathrm{~nm}$.

2.3. Bioguided Isolation of the Active Principle from Gaillardia megapotamica. The cytotoxic ethanol extract of $G$. megapotamica (4 g) was initially subjected to vacuum liquid chromatography on silica gel $(622 \mathrm{~g}, 63-200 \mu \mathrm{m}, 11.0 \AA ̊ 24.0 \mathrm{~cm}$; Macherey \& Nagel) eluted with a step gradient of hexane/ diethyl ether $\left(\mathrm{Et}_{2} \mathrm{O}\right) /$ methanol $(\mathrm{MeOH})$ to yield 12 fractions, which were combined in 8 groups according to their thin layer chromatography (TLC) profile (F1 to F8). Fractions F1 to $\mathrm{F} 5$ and F7 and F8 were not active at the tested concentration $(10 \mu \mathrm{g} / \mathrm{mL})$, while fraction $\mathrm{F} 6$, eluted with $100 \% \mathrm{Et}_{2} \mathrm{O}$, demonstrated cytotoxic effect at this concentration. Therefore, F6 was further processed by radial preparative chromatography using an isocratic mobile phase of hexane/ $\mathrm{Et}_{2} \mathrm{O} 30: 70$. The fractions obtained were combined in 10 groups in accordance with the TLC analysis (F6-1 to F6-10). From fraction F6-6, a pure compound $\mathbf{1}$ was obtained by spontaneous crystallization ( $\mathrm{Rt}=9.65,98.2 \%$ purity, by HPLC). This compound, the remaining F6-6, and the rest of the fractions were further tested for their cytotoxic activity at $10 \mu \mathrm{g} / \mathrm{mL}$. Only 1 exerted a toxic effect at this concentration. According to ${ }^{1} \mathrm{H}$ and ${ }^{13} \mathrm{C}$ NMR spectra (copies of the original spectra are obtainable from the corresponding author), the compound was identified as the sesquiterpene lactone helenalin $\mathrm{C}_{15} \mathrm{H}_{18} \mathrm{O}_{4}(\mathbf{1}$; $\mathrm{m} / z$ 262) [41] (yield $0.79 \mathrm{~g} / 100 \mathrm{~g}$ of dried and crushed plant material, by HPLC) (Figure 1).

2.4. Cell Lines and Culture Conditions. The cytotoxicity of plant extracts was tested on acute lymphoblastic leukemia (ALL) CCRF-CEM cells [42] and on CML K562 cells [43] and their MDR P-gp overexpressing variants, CEM/ADR5000 and Lucena 1 , respectively $[8,44]$. Cell lines were routinely maintained in RPMI-1640 medium supplemented with $10 \%$ heat-inactivated fetal bovine serum (FBS, Natacor, Córdoba, Argentina), $2 \mathrm{mM}$ L-glutamine (Invitrogen Life Technologies, CA, USA), $100 \mathrm{U} / \mathrm{mL}$ penicillin (Invitrogen Life Technologies, CA, USA), and $100 \mu \mathrm{g} / \mathrm{mL}$ streptomycin (Invitrogen Life Technologies, CA, USA) in a $5 \% \mathrm{CO}_{2}$ humidified atmosphere at $37^{\circ} \mathrm{C}$.

As previously described, CEM/ADR5000 cells were exposed once a week to doses of DOX, gradually increasing from 1.7 to $8.6 \mu \mathrm{M}$. The latter concentration was then used for cell maintenance $[44,45]$. Lucena 1 were continuously cultured in the presence of $60 \mathrm{nM}$ DOX in order to maintain 
P-gp overexpression [8]. Both cell lines were grown in drugfree medium 3-4 days before the experiments. Cells were subcultured twice a week and used before the 20th passage. All experiments were performed with cells in the logarithmic growth phase, with cell viabilities over $90 \%$, determined by trypan blue staining.

2.5. Cell Proliferation Assay. To investigate the cytotoxic potential of the extracts, fractions, and the pure compound, the MTT colorimetric assay was performed [46]. Briefly, $5 \times$ $10^{4}$ cells, suspended in $100 \mu \mathrm{L}$ of growth medium, were seeded in 96-well plates containing $100 \mu \mathrm{L}$ of medium in the presence of each tested extract, fraction, or compound previously dissolved in DMSO (final concentration $1 \% \mathrm{v} / \mathrm{v}$ since no adverse effects on cell growth were observed at this concentration). The extracts were evaluated at a final concentration of $50 \mu \mathrm{g} / \mathrm{mL}$. Following the primary screening, those extracts with promising activity on all studied cells were tested at serial dilutions ranging from 50 to $0.012 \mu \mathrm{g} / \mathrm{mL}$. The isolated compound was tested at $0.005-10 \mu \mathrm{g} / \mathrm{mL}$. After 48 or $72 \mathrm{~h}$ for CML or ALL, respectively, $20 \mu \mathrm{L}$ of $5 \mathrm{mg} / \mathrm{mL}$ solution of MTT in sterile PBS was added to each well and further incubated for $4 \mathrm{~h}$. Then, the supernatants were removed and replaced with $100 \mu \mathrm{L}$ DMSO to solubilize the resulting purple formazan crystals produced from metabolically viable cells. Absorbance was measured with an iMark microplate reader (Bio-Rad, USA) at $595 \mathrm{~nm}$. Two wells were used for each sample assayed and three independent experiments were performed.

Untreated and DMSO (1\%)-treated cells were used as controls, while DOX (added to reach final concentrations of 0.003 to $40 \mu \mathrm{g} / \mathrm{mL}$ ) was used as reference. The percentage of cytotoxic activity was determined by the following formula: cytotoxicity $(\%)=[1-($ optical density of treated cells-optical density DMSO)/(optical density of control cells-optical density $\mathrm{DMSO})] \times 100$.

Half-maximal inhibitory concentrations $\left(\mathrm{IC}_{50}\right)$, the concentrations of the tested samples required to inhibit $50 \%$ cell proliferation, were calculated from the mean values of data from wells. Resistance factors (RF) were calculated by dividing the $\mathrm{IC}_{50}$ of resistant cells by the $\mathrm{IC}_{50}$ of the corresponding sensitive cell line [47].

2.6. Cytotoxicity on Peripheral Blood Mononuclear Cells (PBMC). The cytotoxicity of the extracts on peripheral blood mononuclear cells (PBMC) was evaluated by MTT assay [46]. PBMC were collected from fresh heparinized blood and separated by density gradient centrifugation (Ficoll ${ }^{\circledR}$ ) as described by Rennó et al. [48]. As the current study required samples from healthy human volunteer donors, ethical approval was provided by the Catholic University of Córdoba Research Ethics Board. Signed informed consent was obtained from donors. For the cytotoxicity assay, $1 \times 10^{5} \mathrm{PBMC} /$ well was incubated in duplicate in 96-well plates with PHA $10 \mu \mathrm{g} / \mathrm{mL}$, in the presence of increasing concentrations of the extracts $(0.05-50 \mu \mathrm{g} / \mathrm{mL})$ or $1 \%$ DMSO for $48 \mathrm{~h}$. Absorbance (Abs) and percentage of cytotoxicity were determined as described above and the $\mathrm{IC}_{50}$ values were calculated.

2.7. Statistical Analysis. The results are expressed as mean \pm SE. Data were analyzed with one-way analysis of variance
(ANOVA) and one-tailed unpaired $t$ test using GraphPad Prism software (GraphPad Prism 5.0, GraphPad Software, Inc., CA, USA), with $p$ values $\leq 0.05$ as statistically significant. $\mathrm{IC}_{50} \mathrm{~s}$ were calculated by GraphPad Prism software, responding to at least five concentrations of each extract at the $95 \%$ confidence level with upper and lower confidence limits.

\section{Results and Discussion}

With the aim of finding new agents capable of interfering with the proliferation of sensitive and MDR leukemia cells, 91 ethanol extracts obtained from different plant species of Central Argentina were primarily assayed at a fixed concentration of $50 \mu \mathrm{g} / \mathrm{mL}$ against a panel of cells consisting of CCRF-CEM and K562 and their respective P-gp overexpressing counterparts, CEM/ADR5000 and Lucena 1. The ethanol extracts obtained from Aldama tucumanensis, Ambrosia elatior, Baccharis artemisioides, Baccharis coridifolia, Dimerostemma aspilioides, Gaillardia megapotamica, and Vernonanthura nudiflora inhibited proliferation by $93-100 \%$ in ALL cell lines while 70-90\% inhibition was observed in the CML cells (Table 1). As observed, all the active species belong to Asteraceae. This could be due to more than a third of the studied plants being Asteraceae (35\%) while the remaining 65\% were Amaranthaceae (1\%), Apiaceae (1\%), Apocynaceae (1\%), Aristolochiaceae (1\%), Asclepiadaceae (1\%), Bignoniaceae (4\%), Boraginaceae (1\%), Capparaceae (1\%), Chenopodiaceae (1\%), Dipsacaceae (1\%), Euphorbiaceae (2\%), Fabaceae $(8 \%)$, Lamiaceae $(8 \%)$, Lomariopsidaceae (1\%), Loranthaceae (1\%), Malvaceae (4\%), Meliaceae (1\%), Papaveraceae (1\%), Poaceae (4\%), Polygalaceae (1\%), Ranunculaceae (1\%), Rhamnaceae (1\%), Rosaceae (2\%), Rutaceae (1\%), Santalaceae (1\%), Schizaeaceae (1\%), Solanaceae (3\%), Verbenaceae (4\%), and Zygophyllaceae (1\%). Sesquiterpene lactones are characteristic compounds among Asteraceae [49] and many of these exhibit cytotoxic properties [50, 51]. It is interesting that Mandevilla pentlandiana and Microliabum candidum displayed a complete inhibitory effect on the proliferation of both ALL cell lines with moderate activity on CML cell lines (Table 1). Bibliographic information about the traditional uses, biological activity, and chemical constituents of the most active plants is listed in Table 2.

These active extracts were further assessed for their $\mathrm{IC}_{50}$ values in order to determine their level of effectiveness. As observed in Table $3, \mathrm{IC}_{50}$ ranged from 0.37 to $29.44 \mu \mathrm{g} / \mathrm{mL}$. All extracts, except $A$. tucumanensis and A. elatior against CML cell lines, showed a strong cytotoxic effect with $\mathrm{IC}_{50}$ values lower than $20 \mu \mathrm{g} / \mathrm{mL}$. This value is the threshold established by the National Cancer Institute (USA, NCI) plant screening program for an extract to be considered active following an incubation period of 48 and $72 \mathrm{~h}$ [52]. As observed, most of them showed $\mathrm{IC}_{50}$ values lower than $7 \mu \mathrm{g} / \mathrm{mL}$. The $G$. megapotamica and D. aspilioides extracts were the most effective among those with less toxic effect on PBMC.

The A. elatior extract was highly specific, since it showed outstanding proliferation-inhibiting properties against ALL cells but not against CML cells $(p<0.05)$. The extract obtained from $D$. aspilioides, although active against all the cell lines, also induced specific cytotoxic activity, being more 


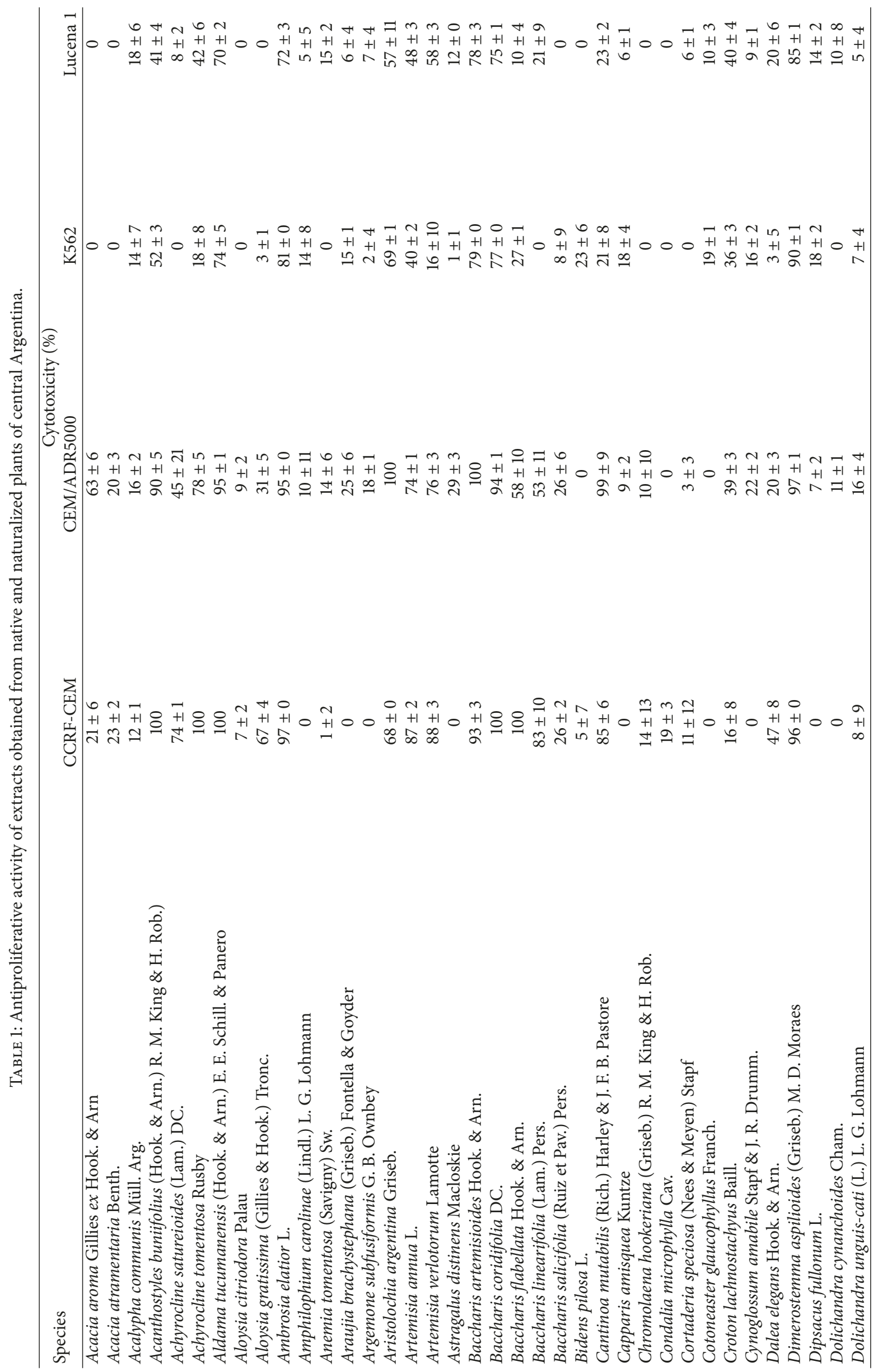




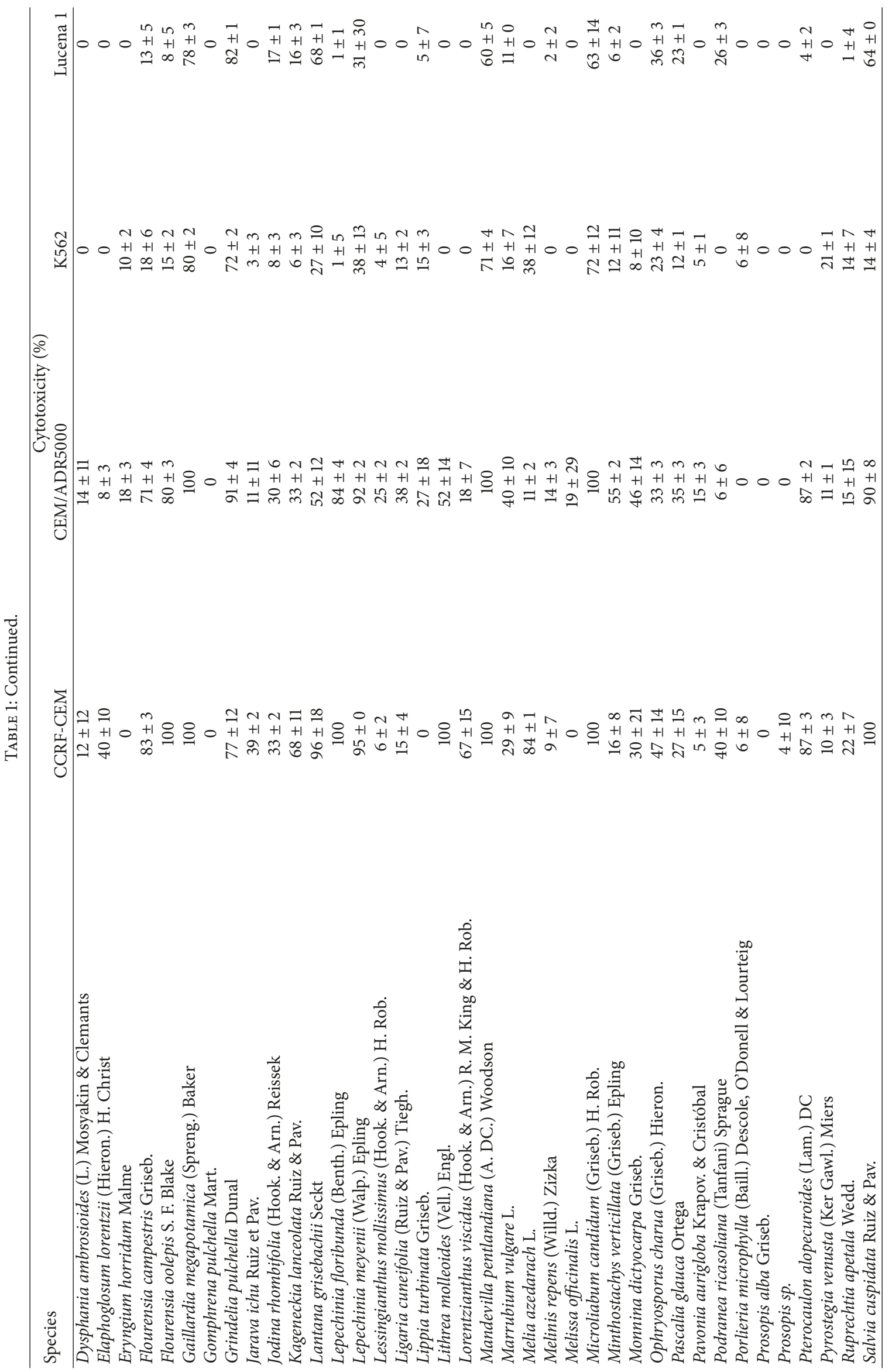




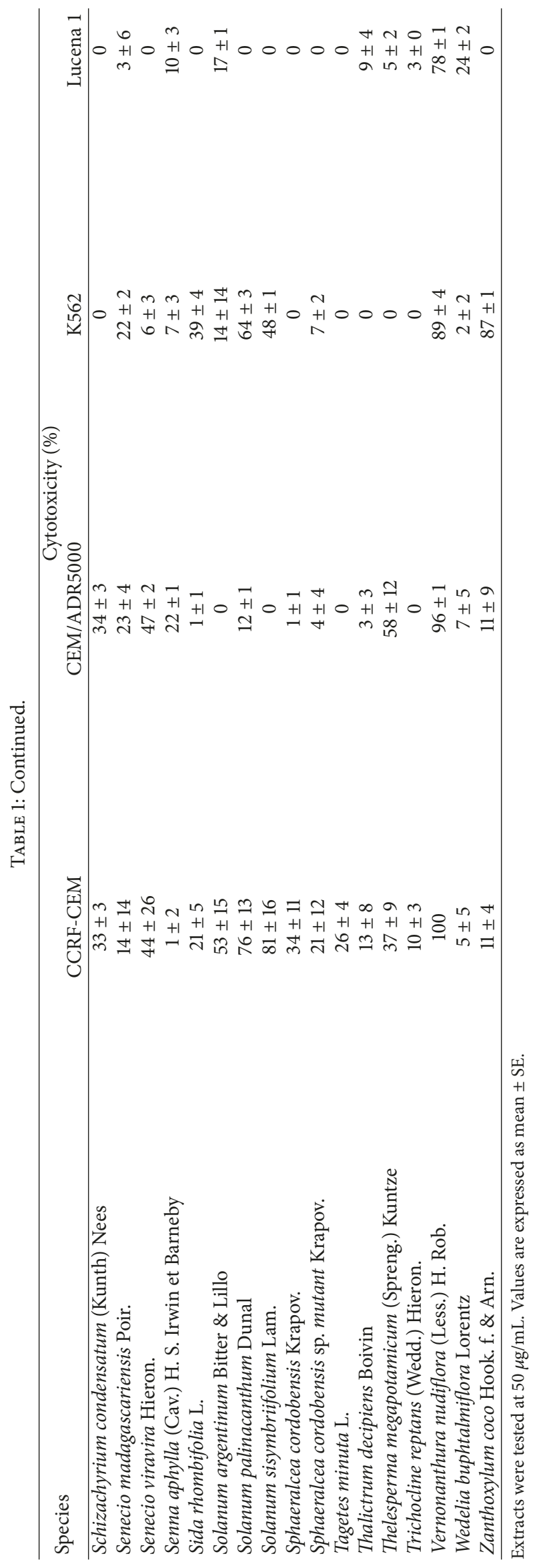




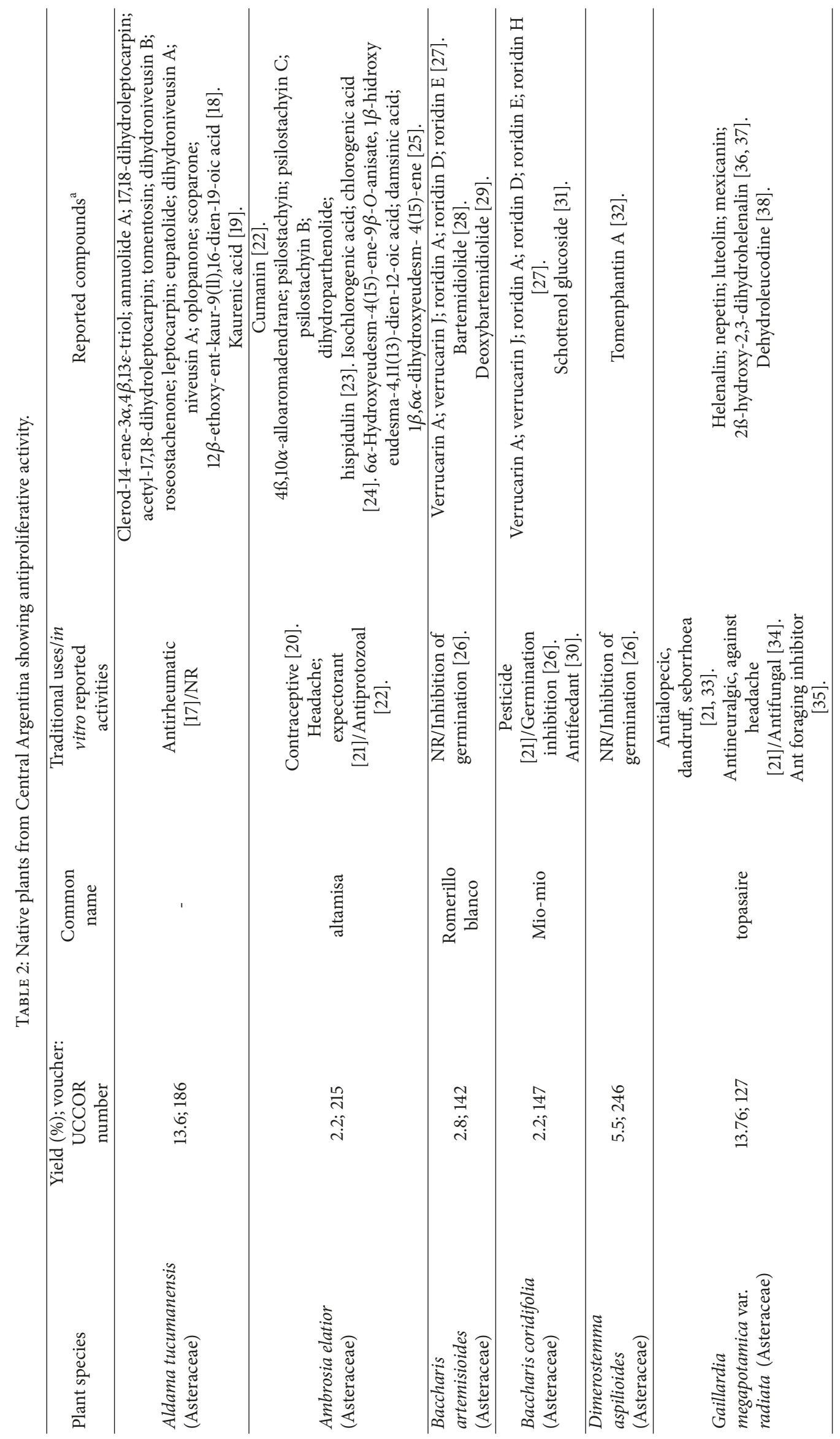




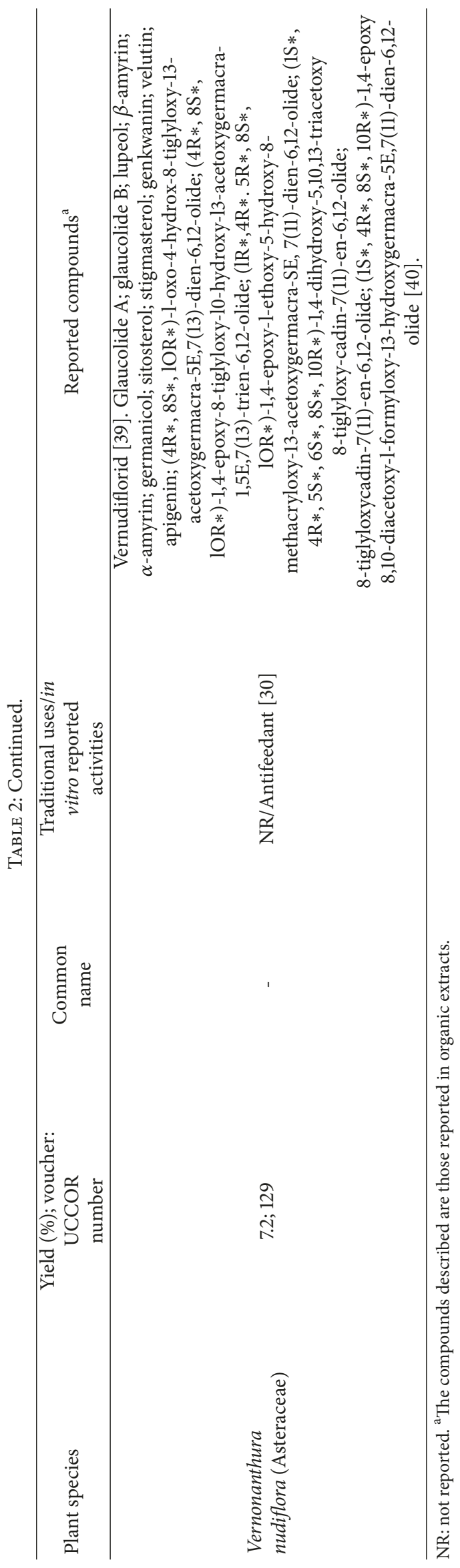


TABLE 3: Half-maximal inhibitory concentrations of most effective extracts.

\begin{tabular}{|c|c|c|c|c|c|c|c|}
\hline \multirow{2}{*}{ Species } & \multicolumn{7}{|c|}{$\mathrm{IC}_{50}(\mu \mathrm{g} / \mathrm{mL})($ mean $\pm \mathrm{SE})$} \\
\hline & CCRF-CEM & CEM/ADR5000 & $\mathrm{RF}$ & K562 & Lucena 1 & $\mathrm{RF}$ & PBMC \\
\hline Aldama tucumanensis & $5.39 \pm 0.23^{\mathrm{a}, * * *}$ & $17.56 \pm 0.50^{\mathrm{a}, \mathrm{b}, * * *}$ & 3.26 & $20.24 \pm 1.26^{\mathrm{a}, \mathrm{b}, * * *}$ & $29.44 \pm 5.82^{\mathrm{b}, \dagger}$ & 1.45 & $9.13 \pm 1.84$ \\
\hline Ambrosia elatior & $5.84 \pm 1.07^{\mathrm{a}, * *}$ & $2.73 \pm 0.63^{\mathrm{a}, * * *}$ & 0.47 & $19.16 \pm 2.48^{\mathrm{b}, * *, \dagger}$ & $21.93 \pm 2.91^{\mathrm{b}, \dagger \dagger}$ & 1.14 & $4.01 \pm 0.67$ \\
\hline Baccharis artemisioides & $1.15 \pm 0.10^{\mathrm{a}, * * *}$ & $0.94 \pm 0.24^{\mathrm{a}, * * *}$ & 0.82 & $1.90 \pm 0.33^{\mathrm{a}, *}$ & $5.74 \pm 0.14^{\mathrm{b}, * * *, \dagger \dagger \dagger}$ & 3.02 & $0.95 \pm 0.21$ \\
\hline Baccharis coridifolia & $0.37 \pm 0.03^{\mathrm{a}, * * *}$ & $5.89 \pm 0.87^{\mathrm{b}, * * *, \dagger \dagger \dagger}$ & 15.92 & $0.51 \pm 0.07^{\mathrm{a}}$ & $1.08 \pm 0.11^{\mathrm{a}, * * *}$ & 2.12 & $0.08 \pm 0.01$ \\
\hline Dimerostemma aspilioides & $1.60 \pm 0.07^{\mathrm{a}, * * *}$ & $1.18 \pm 0.30^{\mathrm{a}, * * *}$ & 0.74 & $6.89 \pm 0.50^{\mathrm{b}, * * *, \dagger}$ & $10.38 \pm 1.16^{\mathrm{b}, * *, \dagger \dagger}$ & 1.51 & $2.69 \pm 0.53$ \\
\hline Gaillardia megapotamica & $0.70 \pm 0.03^{\mathrm{a}, * * *}$ & $1.21 \pm 0.005^{\mathrm{b}, * * *}$ & 1.73 & $2.77 \pm 0.02^{\mathrm{c}, * * *}$ & $5.95 \pm 0.17^{\mathrm{d}, * * *, \dagger}$ & 2.15 & $2.76 \pm 0.52$ \\
\hline Vernonanthura nudiflora & $2.21 \pm 0.08^{\mathrm{a}, * * *, \dagger \dagger}$ & $6.38 \pm 0.20^{\mathrm{b}, * * *, \dagger}$ & 2.89 & $6.41 \pm 0.91^{\mathrm{b}, * *, \dagger}$ & $10.76 \pm 0.78^{\mathrm{c}, * *}$ & 1.68 & $13.70 \pm 1.06$ \\
\hline doxorubicin & $0.07 \pm 0.0006^{\mathrm{a}}$ & $>40^{\dagger \dagger \dagger}$ & $>571$ & $0.78 \pm 0.14^{\mathrm{a}}$ & $22.99 \pm 1.18^{\mathrm{b}, \dagger \dagger \dagger}$ & 29.47 & $0.39 \pm 0.02$ \\
\hline
\end{tabular}

Results represent the mean \pm SE. Means followed by the same letter in each row were not significantly different (Tukey, $p>0.05$ ). Statistical comparisons between extracts and doxorubicin were analyzed by one-tailed unpaired $t$ test. $* * *$ indicates $p<0.001, * *$ indicates $p<0.01$, and $*$ indicates $p<0.05$. Statistical comparisons between leukemia cells with respect to PBMC were analyzed by ANOVA-Tukey's multiple comparison test. $\dagger \dagger \dagger$ indicates $p<0.001$, $\dagger \dagger$ indicates $p<0.01$, and $\dagger$ indicates $p<0.05$.

effective on ALL cell lines than on CML cells $(p<0.05)$. B. artemisioides and B. coridifolia extracts were highly potent, being equally active $(p>0.05)$ against almost all the assayed cell lines, with $\mathrm{IC}_{50}$ values from 0.37 to $5.89 \mu \mathrm{g} / \mathrm{mL}$, and at the same time were the most toxic against PBMC. Most of the extracts showed significantly different cytotoxic effects $(p<$ 0.001-0.05) with respect to DOX, with the same or lower activity in the case of CCRF-CEM and K562, but the same or greater effectiveness in the resistant cells, CEM/ADR5000 and Lucena 1 . The latter were $>570$-fold and 29 -fold more resistant to DOX than their parental cell lines, CCRF-CEM and K562, respectively (Table 3).

It is remarkable that extracts from A. elatior and $D$. aspilioides displayed collateral sensitivity (CS) with CEM/ ADR5000 compared to the parental cell line CCRF-CEM (degree of resistance 0.47 and 0.74 , resp.) and lack of crossresistance regarding Lucena 1 . Except $B$. coridifolia, to which both P-gp overexpressing cells showed cross-resistance, the rest of the extracts showed this phenomenon only in one resistant cell. This classification is taken into consideration following Hall et al., [53] who defined RF values $\geq 2$ as significant cross-resistance toward a compound, while values lower than 1 indicate a CS agent.

As mentioned, G. megapotamica was identified as one of the most active species. After submitting this plant to bioguided isolation, helenalin (1) was obtained. This sesquiterpene lactone showed outstanding $\mathrm{IC}_{50}$ values against $\mathrm{K} 562$ cells and their MDR counterpart Lucena 1 of $0.63 \pm 0.06$ and $0.74 \pm 0.06 \mu \mathrm{g} / \mathrm{mL}$, respectively $(2.53 \pm 0.05$ and $2.83 \pm 0.24 \mu \mathrm{M}$, resp.) while $0.19 \pm 0.01$ and $0.16 \pm 0.01 \mu \mathrm{g} / \mathrm{mL}$ were obtained against CCRF-CEM and its respective drug-resistant phenotype CEM/ADR5000 $(0.74 \pm 0.05$ and $0.59 \pm 0.05 \mu \mathrm{M}$, resp.). In coincidence with the results obtained for the complete extract, ALL cells were more sensitive to compound $\mathbf{1}$ than CML cells.

Although none of these most active species have been subjected to bioguided isolation to obtain their cytotoxic principles, there is some related information regarding toxicity on cancer cells of some of their constituents. Leptocarpin, present in A. tucumanensis, displayed cytotoxic activity against HT-29, PC-3, DU-145, MDA-MB-231, and MCF7 cells, with $\mathrm{IC}_{50}$ values in the range of 0.72 to $2.32 \mu \mathrm{g} / \mathrm{mL}$, by inducing apoptotic death [54]. The values show that this compound can be considered as active, based on the $4 \mu \mathrm{g} / \mathrm{mL}$ cutoff established by the NCI to identify good cytotoxic compounds [55]. Eupatolide, a germacranolide sesquiterpene lactone also found in this plant, showed potent cytotoxic activity with an $\mathrm{IC}_{50}$ of $0.47 \mu \mathrm{g} / \mathrm{mL}$ against H.Ep.-2 cell line [56]. The flavonoid hispidulin, present in A. elatior, has been tested for cytotoxic activity against Jurkat E6-1, GLC4, and COLO320 cells, showing $\mathrm{IC}_{50}$ ranging from 10.21 to $24.62 \mu \mathrm{g} / \mathrm{mL}$ [57, 58]. Other constituents of this plant, dihydroparthenolide and psilostachyin, were reported as inactive when tested against KB cells [59]; the same as was found for damsinic acid tested against U937, Jurkat and Molt 4 [60], while psilostachyin C showed no effectiveness against HeLa, MCF7, or A431 cell lines [61] but was slightly effective against BW5147 cells, with an $\mathrm{IC}_{50}$ value of $4.89 \mu \mathrm{g} / \mathrm{mL}$ [62]. Chlorogenic acid showed $\mathrm{IC}_{50}$ values ranging from $1.8-10.7 \mu \mathrm{g} / \mathrm{mL}$ against HepG2, Hep2, HCT116, RD, and MCF7 [63].

All the Argentinian plants of B. coridifolia and most of B. artemisioides studied by Rizzo et al. [27] were positive for the fungal macrocyclic trichothecenes roridins $\mathrm{E}$ and $\mathrm{H}$ and verrucarins $A$ and $J$, which showed strong cytotoxic activity with $\mathrm{IC}_{50}$ of $0.0018,0.0055,0.0012$ and $0.0022 \mu \mathrm{g} / \mathrm{mL}$, respectively against H4TG cells [64]. When tested against Hep2 , verrucarin $A$ showed an $\mathrm{IC}_{50}$ value of $0.002 \mu \mathrm{g} / \mathrm{mL}$ [65] while verrucarins $\mathrm{A}, \mathrm{J}$ and roridin $\mathrm{E}$ were active in the range from 0.0005 to $0.0042 \mu \mathrm{g} / \mathrm{mL}$ against $\mathrm{KB}$ and BC1 cells [66]. The compound schottenol glucoside, present in B. coridifolia, demonstrated a toxic effect against $\mathrm{KB}$ cells with an $\mathrm{IC}_{50}$ value of $2.7 \mu \mathrm{g} / \mathrm{mL}$ [31]. The germacranolide tomenphantin $\mathrm{A}$, isolated from $D$. aspilioides, showed moderate activity against $\mathrm{KB}$ cells, with an $\mathrm{IC}_{50}$ of $3.0 \mu \mathrm{g} / \mathrm{mL}$ [67].

Some sesquiterpene lactones, among them helenalin and mexicanin, were obtained from G. megapotamica. Helenalin, with a mean cytotoxic activity of $0.10 \mu \mathrm{g} / \mathrm{mL}$ against EN2 cells [68] induced apoptosis in Jurkat $\mathrm{T}$ cells [69] and inhibited human telomerase activity [70], among other toxic effects in cancer cells [71]. The activity reported in this work toward the resistant cell lines makes this compound attractive as a starting point for obtaining effective cytotoxics against 
multidrug-resistant cells. Mexicanin showed outstanding toxic effects with an $\mathrm{IC}_{50}$ of $0.14 \mu \mathrm{g} / \mathrm{mL}$ against EN2 cells [68]. Dehydroleucodine exhibited cytotoxicity against a panel of tumor cells, including eight leukemia cell lines, with $\mathrm{IC}_{50}$ ranging from 1.22 to $4.62 \mu \mathrm{g} / \mathrm{mL}$ [72], and luteolin showed $\mathrm{IC}_{50}$ of 11.70 and $9.30 \mu \mathrm{g} / \mathrm{mL}$ against GLC4 and COLO320 cells, respectively [57]. V. nudiflora contains many inactive compounds, such as genkwanin, with an $\mathrm{IC}_{50}$ against $\mathrm{KB}$ and P388 cells of 8.7 and $10 \mu \mathrm{g} / \mathrm{mL}$, respectively [73] and germanicol, with $\mathrm{IC}_{50} 29.5$ and $35.6 \mu \mathrm{g} / \mathrm{mL}$ against HCT 116 and A549 cell lines, respectively [74], as well as the effective compound velutin $\left(\mathrm{IC}_{50}=1.5 \mu \mathrm{g} / \mathrm{mL}\right.$ against $\mathrm{KB}$ cells $)$ [73]. In addition, apigenin showed $\mathrm{IC}_{50}$ values from 7.29 to $16.39 \mu \mathrm{g} / \mathrm{mL}$ against Jurkat E6-1, GLC4, and COLO320 cell lines [57, 58]. A mixture of sitosterol and stigmasterol exhibited no cytotoxic effects against P-388 and HT-29 up to a concentration of $50 \mu \mathrm{g} / \mathrm{mL}$ [75].

\section{Conclusions}

This study demonstrated that compound $\mathbf{1}$, isolated from G. megapotamica, is a promising cytotoxic with outstanding activity against K562 and CCRF-CEM and their respective MDR counterparts, Lucena 1 and CEM/ADR5000. This identifies this sesquiterpene lactone as an important lead for obtaining therapeutics to act against resistant leukemia cells.

The outstanding antileukemia effect of $D$. aspilioides and the scant information about its components and the hypersensitivity of resistant CEM/ADR5000 cells toward its extract merit further investigation to obtain potential candidates for improving leukemia chemotherapies, especially against resistant phenotypes.

\section{Abbreviations}

ALL: Acute lymphoblastic leukemia

CML: Chronic myelogenous leukemia

CS: Collateral sensitivity

$\mathrm{IC}_{50}$ : Half-maximal inhibitory concentration

MDR: Multidrug resistance

MTT: 3-(4,5-Dimethyl-2-thiazolyl)-2,5-

diphenyl-2H-tetrazolium

bromide

PBMC: Peripheral blood mononuclear cells

P-gp: P-glycoprotein

RF: $\quad$ Resistance factor.

\section{Conflicts of Interest}

The authors declare that there are no conflicts of interest regarding the publication of this paper.

\section{Acknowledgments}

This work was supported by the Roemmers Foundation, the Catholic University of Córdoba, MINCyT Córdoba (PID 2012), CONICET (PIP 2011-2013 and PIP 2014-2016), and FONCyT (PICT 2014-1594). CEM/ADR5000 and Lucena 1 were generous gifts from Dr. T. Efferth (Institute of Pharmacy and Biochemistry, Johannes Gutenberg University, Mainz, Germany) and from Dr. V. Rumjanek (Instituto de Bioquímica Médica Leopoldo de Meis, Universidade Federal do Rio de Janeiro, Rio de Janeiro, Brazil), respectively. The authors thank Joss Heywood for revising the English language. María Laura González, María Inés Crespo, and Jerónimo Laiolo acknowledge receipt of a Scholarship from CONICET. María Cecilia Carpinella, Mariana Belén Joray, and Sara María Palacios are staff members of the National Research Council of Argentina (CONICET).

\section{Supplementary Materials}

High performance liquid chromatography (HPLC) fingerprints with UV detection at 210 and $280 \mathrm{~nm}$ and UV spectra of Aldama tucumanensis, Ambrosia elatior, Baccharis artemisioides, Baccharis coridifolia, Dimerostemma aspilioides, Gaillardia megapotamica, and Vernonanthura nudiflora extracts are shown. Analytical HPLC profile of the isolated compound, helenalin, with UV detection at $210 \mathrm{~nm}$ is also shown. (Supplementary Materials)

\section{References}

[1] J.-J. Lin, H.-Y. Hsu, J.-S. Yang et al., "Molecular evidence of antileukemia activity of gypenosides on human myeloid leukemia HL-60 cells in vitro and in vivo using a HL-60 cells murine xenograft model," Phytomedicine, vol. 18, no. 12, pp. 1075-1085, 2011.

[2] J. Ferlay, I. Soerjomataram, R. Dikshit et al., "Cancer incidence and mortality worldwide: sources, methods and major patterns in GLOBOCAN 2012," International Journal of Cancer, vol. 136, no. 5, pp. E359-E386, 2014.

[3] S. D. Cramer, P. D. Aplan, and S. K. Durum, "Therapeutic targeting of IL-7R $\alpha$ signaling pathways in ALL treatment," Blood, vol. 128, no. 4, pp. 473-478, 2016.

[4] J. F. Apperley, "Chronic myeloid leukaemia," The Lancet, vol. 385, no. 9976, pp. 1447-1459, 2015.

[5] S. S. Fard, M. J. Tehrani, and A. M. Ardekani, "Prostaglandin E2 induces growth inhibition, apoptosis and differentiation in $\mathrm{T}$ and $\mathrm{B}$ cell-derived acute lymphoblastic leukemia cell lines (CCRF-CEM and Nalm-6)," Prostaglandins, Leukotrienes and Essential Fatty Acids, vol. 87, no. 1, pp. 17-24, 2012.

[6] R. Senthilkumar, B.-A. Chen, X.-H. Cai, and R. Fu, "Anticancer and multidrug-resistance reversing potential of traditional medicinal plants and their bioactive compounds in leukemia cell lines," Chinese Journal of Natural Medicines, vol. 12, no. 12, pp. 881-894, 2014.

[7] M. S. Topp, P. Kufer, and N. Gökbuget, “Targeted therapy with the T-cell-engaging antibody blinatumomab of chemotherapyrefractory minimal residual disease in B-lineage acute lymphoblastic leukemia patients results in high response rate and prolonged leukemia-free survival," Journal of Clinical Oncology, vol. 29, no. 18, pp. 2493-2498, 2011.

[8] M. L. González, D. Mariano A. Vera, J. Laiolo et al., "Mechanism underlying the reversal of drug resistance in P-glycoproteinexpressing leukemia cells by pinoresinol and the study of a derivative," Frontiers in Pharmacology, vol. 8, article no. 205, 2017. 
[9] P. Ferrao, P. Sincock, S. Cole, and L. Ashman, "Intracellular Pgp contributes to functional drug efflux and resistance in acute myeloid leukaemia," Leukemia Research, vol. 25, no. 5, pp. 395405, 2001.

[10] G. Szakács, J. K. Paterson, J. A. Ludwig, C. Booth-Genthe, and M. M. Gottesman, "Targeting multidrug resistance in cancer," Nature Reviews Drug Discovery, vol. 5, no. 3, pp. 219-234, 2006.

[11] Y. Kuwazuru, A. Yoshimura, S. Hanada et al., "Expression of the multidrug transporter, P-glycoprotein, in chronic myelogenous leukaemia cells in blast crisis," British Journal of Haematology, vol. 74, no. 1, pp. 24-29, 1990.

[12] M. Filipits, T. Stranzl, G. Pohl et al., "Drug resistance factors in acute myeloid leukemia: a comparative analysis," Leukemia, vol. 14, no. 1, pp. 68-76, 2000.

[13] M. B. Joray, M. R. del Rollán, G. M. Ruiz, S. M. Palacios, and M. C. Carpinella, "Antibacterial activity of extracts from plants of central Argentina-isolation of an active principle from Achyrocline satureioides," Planta Medica, vol. 77, no. 1, pp. 95100, 2011.

[14] M. E. Chiari, M. B. Joray, G. Ruiz, S. M. Palacios, and M. C. Carpinella, "Tyrosinase inhibitory activity of native plants from central Argentina: isolation of an active principle from Lithrea molleoides," Food Chemistry, vol. 120, no. 1, pp. 10-14, 2010.

[15] M. E. Chiari, L. Tosoni, M. B. E. Joray et al., "The inhibitory activity of plants from central Argentina on p-Hydroxyphenylpyruvate dioxygenase. Isolation and mechanism of inhibition of a flavanone from Flourensia oolepis," Planta Medica, vol. 81, no. 15, pp. 1382-1391, 2015.

[16] M. B. Joray, F. Villafañez, M. L. González et al., "P53 tumor suppressor is required for efficient execution of the death program following treatment with a cytotoxic limonoid obtained from Melia azedarach," Food and Chemical Toxicology, vol. 109, pp. 888-897, 2017.

[17] G. C. Giberti, "Herbal folk medicine in northwestern Argentina: compositae," Journal of Ethnopharmacology, vol. 7, no. 3, pp. 321-341, 1983.

[18] K. M. Meragelman, L. A. Espinar, V. E. Sosa, M. L. Uriburu, and J. R. De La Fuente, "Terpenoid constituents of Viguiera tucumanensis," Phytochemistry, vol. 41, no. 2, pp. 499-502, 1996.

[19] C. E. Vaccarini, S. M. Palacios, K. M. Meragelman, and V. E. Sosa, "Antifeedant activity of metabolites from Viguiera tucumanensis," Natural Product Research (Formerly Natural Product Letters), vol. 16, no. 5, pp. 323-327, 2002.

[20] G. Schmeda-Hirschmann and E. Bordas, "Paraguayan medicinal compositae," Journal of Ethnopharmacology, vol. 28, no. 2, pp. 163-171, 1990.

[21] M. E. Goleniowski, G. A. Bongiovanni, L. Palacio, C. O. Nuñez, and J. J. Cantero, "Medicinal plants from the "Sierra de Comechingones", Argentina," Journal of Ethnopharmacology, vol. 107, no. 3, pp. 324-341, 2006.

[22] V. P. Sülsen, S. I. Cazorla, F. M. Frank et al., "Natural terpenoids from Ambrosia species are active in vitro and in vivo against human pathogenic trypanosomatids," PLOS Neglected Tropical Diseases, vol. 7, no. 10, Article ID e2494, 2013.

[23] G. L. Silva, J. C. Oberti, and W. Herz, "Sesquiterpene lactones and other constituents of argentine Ambrosia species," Phytochemistry, vol. 31, no. 3, pp. 859-861, 1992.

[24] E. L. Rice, "Inhibition of nitrogen-fixing and nitrifying bacteria by seed plants IV. The inhibitors produced by Ambrosia elatior and A. psilostachya," The Southwestern Naturalist, vol. 10, no. 4, p. 248, 1965.
[25] T. Ohmoto, S. Nomura, M. Shimizu, S. Saito, and K. Ikeda, "Studies on the Sesquiterpenes from Ambrosia elatior LINNÉ," Chemical \& Pharmaceutical Bulletin, vol. 35, no. 6, pp. 22722279, 1987.

[26] S. M. Palacios, S. del Corral, M. C. Carpinella, and G. Ruiz, "Screening for natural inhibitors of germination and seedling growth in native plants from Central Argentina," Industrial Crops and Products, vol. 32, no. 3, pp. 674-677, 2010.

[27] I. Rizzo, E. Varsavky, M. Haidukowski, and H. Frade, "Macrocyclic trichothecenes in Baccharis coridifolia plants and endophytes and Baccharis artemisioides plants," Toxicon, vol. 35, no. 5, pp. 753-757, 1997.

[28] C. E. Tonn, O. S. Giordano, R. Bessalle, F. Frolow, and D. Lavie, "The structure of bartemidiolide, a clerodane-type diterpene from Baccharis artemisioides," Phytochemistry, vol. 27, no. 2, pp. 489-491, 1988

[29] C. E. Tonn, O. S. Giordano, J. D. Martín, and V. S. Martín, "Deoxybartemidiolide, a clerodane-type diterpene from Baccharis artemisioides," Phytochemistry, vol. 28, no. 5, pp. 1537-1538, 1989.

[30] S. Del Corral, G. N. D. Napal, M. Zaragoza, M. C. Carpinella, G. Ruiz, and S. M. Palacios, "Screening for extracts with insect antifeedant properties in native plants from central Argentina," Bol Latinoamer Caribe Plant Med Aromat, vol. 13, pp. 498-505, 2014.

[31] M. Arisawa, A. D. Kinghorn, G. A. Cordell, C. H. Phoebe, and N. R. Fansworth, "Plant anticancer agents XXXVI. Schottenol glucoside from Baccharis coridifolia and Ipomopsis aggregata," Planta Medica, vol. 51, no. 6, pp. 544-545, 1985.

[32] G. L. Silva, R. R. Gil, V. E. Sosa, and A. R. Suárez, "Structural and conformation analysis of sesquiterpene lactones by proton nuclear magnetic resonance," Phytochemical Analysis, vol. 3, no. 6, pp. 258-262, 1992.

[33] L. Del Vitto, E. Petenatti, and M. Petenatti, "Recursos herbolarios de San Luis (República Argentina)," 1a Parte: Plantas nativas, pp. 49-66, 1997, Multequina.

[34] L. Svetaz, F. Zuljan, M. Derita et al., "Value of the ethnomedical information for the discovery of plants with antifungal properties. A survey among seven Latin American countries," Journal of Ethnopharmacology, vol. 127, no. 1, pp. 137-158, 2010.

[35] G. N. Diaz Napal, L. M. Buffa, L. C. Nolli et al., "Screening of native plants from central Argentina against the leaf-cutting ant Acromyrmex lundi (Guérin) and its symbiotic fungus," Industrial Crops and Products, vol. 76, pp. 275-280, 2015.

[36] E. M. Petenatti, M. J. Pestchanker, L. A. Del Vitto, and E. Guerreiro, "Chemotoxonomy of the Argentinian species of Gaillardia," Phytochemistry, vol. 42, no. 5, pp. 1367-1368, 1996.

[37] E. Lozano, P. Barrera, R. Salinas et al., "Sesquiterpene lactones and the diterpene 5-epi-icetexone affect the intracellular and extracellular stages of Trypanosoma cruzi," Parasitology International, vol. 61, no. 4, pp. 628-633, 2012.

[38] V. Jimenez, U. Kemmerling, R. Paredes, J. D. Maya, M. A. Sosa, and N. Galanti, "Natural sesquiterpene lactones induce programmed cell death in Trypanosoma cruzi: a new therapeutic target?" Phytomedicine, vol. 21, no. 11, pp. 1411-1418, 2014.

[39] C. Y. Looi, B. Moharram, and M. Paydar, "Induction of apoptosis in melanoma A375 cells by a chloroform fraction of Centratherum anthelminticum (L.) seeds involves NF-kappaB, p53 and Bcl-2-controlled mitochondrial signaling pathways," $B M C$ Complementary and Alternative Medicine, vol. 13, no. 1, p. 166, 2013.

[40] A. Bardón, N. I. Kamiya, C. A. De Ponce De Léon, C. A. N. Catalán, J. G. Díaz, and W. Herz, "Glaucolides and related 
sesquiterpene lactones from Vernonia nudiflora and Chrysolaena propinqua," Phytochemistry, vol. 31, no. 2, pp. 609-613, 1992.

[41] U. Rychlewska, M. Buděšínský, B. Szczepanska, E. Błoszyk, and M. Holub, "Two Crystalline Forms of Sesquiterpene Lactone Helenalin-X-Ray and NMR Study," Collection of Czechoslovak Chemical Communications, vol. 60, no. 2, pp. 276-299, 1995.

[42] T. Efferth, M. Davey, A. Olbrich, G. Rücker, E. Gebhart, and R. Davey, "Activity of drugs from traditional chinese medicine toward sensitive and MDR1- or MRP1-overexpressing multidrug-resistant human CCRF-CEM leukemia cells," Blood Cells, Molecules, and Diseases, vol. 28, no. 2, pp. 160-168, 2002.

[43] V. M. Rumjanek, R. S. Vidal, and R. C. Maia, "Multidrug resistance in chronic myeloid leukaemia: how much can we learn from MDR-CML cell lines?” Bioscience Reports, vol. 33, no. 6, Article ID e00081, 2013.

[44] A. Kimmig, V. Gekeler, M. Neumann et al., "Susceptibility of multidrug-resistant human leukemia cell lines to human interleukin 2-activated killer-cells," Cancer Research, vol. 50, no. 21, pp. 6793-6799, 1990.

[45] M. Saeed, H. Khalid, Y. Sugimoto, and T. Efferth, "The lignan, (-)-sesamin reveals cytotoxicity toward cancer cells: pharmacogenomic determination of genes associated with sensitivity or resistance," Phytomedicine, vol. 21, no. 5, pp. 689-696, 2014.

[46] M. B. Joray, L. D. Trucco, M. L. González et al., "Antibacterial and cytotoxic activity of compounds isolated from Flourensia oolepis," Evidence-Based Complementary and Alternative Medicine, vol. 2015, Article ID 912484, 11 pages, 2015.

[47] M. E. M. Saeed, H. Abdelgadir, Y. Sugimoto, H. E. Khalid, and T. Efferth, "Cytotoxicity of 35 medicinal plants from Sudan towards sensitive and multidrug-resistant cancer cells," Journal of Ethnopharmacology, vol. 174, pp. 644-658, 2015.

[48] M. N. Rennó, G. M. Barbosa, P. Zancan et al., "Crude ethanol extract from babassu (Orbignya speciosa): cytotoxicity on tumoral and non-tumoral cell lines," Anais da Academia Brasileira de Ciências, vol. 80, no. 3, pp. 467-476, 2008.

[49] F. C. Seaman, "Sesquiterpene lactones as taxonomic characters in the asteraceae," The Botanical Review, vol. 48, no. 2, pp. 121594, 1982.

[50] D. Chaturvedi, "Sesquiterpene lactones: structural diversity and their biological activities," in Opportunity, Challanges and Scope of Natural Products in Medicinal Chemistry, pp. 313-334, Research Signpost, Trivandrum, India, 2011.

[51] A. Ghantous, H. Gali-Muhtasib, H. Vuorela, N. A. Saliba, and N. Darwiche, "What made sesquiterpene lactones reach cancer clinical trials?" Drug Discovery Therapy, vol. 15, no. 15-16, pp. 668-678, 2010.

[52] A. S. Sufian, K. Ramasamy, N. Ahmat, Z. A. Zakaria, and M. I. M. Yusof, "Isolation and identification of antibacterial and cytotoxic compounds from the leaves of Muntingia calabura L," Journal of Ethnopharmacology, vol. 146, no. 1, pp. 198-204, 2013.

[53] M. D. Hall, M. D. Handley, and M. M. Gottesman, "Is resistance useless? Multidrug resistance and collateral sensitivity," Trends in Pharmacological Sciences, vol. 30, no. 10, pp. 546-556, 2009.

[54] C. Bosio, G. Tomasoni, R. Martínez, A. F. Olea, H. Carrasco, and J. Villena, "Cytotoxic and apoptotic effects of leptocarpin, a plant-derived sesquiterpene lactone, on human cancer cell lines," Chemico-Biological Interactions, vol. 242, pp. 415-421, 2015.

[55] V. Kuete, P. Y. Ango, and S. O. Yeboah, "Cytotoxicity of four Aframomum species (A. arundinaceum, A. alboviolaceum, A. kayserianum and A. polyanthum) towards multi-factorial drug resistant cancer cell lines," BMC Complementary and Alternative Medicine, vol. 14, no. 1, p. 340, 2014.

[56] K. Lee, H. Furukawa, H. Huang, and E. Huang, "Antitumor agents II: Eupatolide, a new cytotoxic principle from eupatorium formosanum hay," Journal of Pharmaceutical Sciences, vol. 61, no. 4, pp. 629-631, 1972.

[57] H. J. Woerdenbag, I. Merfort, C. M. Passreiter et al., "Cytotoxicity of flavonoids and sesquiterpene lactones from Arnica species against the GLC4 and the COLO 320 cell lines," Planta Medica, vol. 60 , no. 5 , pp. 434-437, 1994.

[58] K. Plochmann, G. Korte, E. Koutsilieri et al., "Structure-activity relationships of flavonoid-induced cytotoxicity on human leukemia cells," Archives of Biochemistry and Biophysics, vol. 460, no. 1, pp. 1-9, 2007.

[59] E. Bianchi, C. C. J. Culvenor, and J. W. Loder, "Psilostachyin, a cytotoxic constituent of Ambrosia artemsisiifolia L," Australian Journal of Chemistry, vol. 21, no. 4, pp. 1109-1111, 1968.

[60] M. De Leo, M. B. V. Saltos, B. F. N. Puente, N. De Tommasi, and A. Braca, "Sesquiterpenes and diterpenes from Ambrosia arborescens," Phytochemistry, vol. 71, no. 7, pp. 804-809, 2010.

[61] Q.-F. Chen, Z.-P. Liu, and F.-P. Wang, "Natural sesquiterpenoids as cytotoxic anticancer agents," Mini-Reviews in Medicinal Chemistry, vol. 11, no. 13, pp. 1153-1164, 2011.

[62] R. Martino, M. F. Beer, O. Elso, O. Donadel, V. Sülsen, and C. Anesini, "Sesquiterpene lactones from Ambrosia spp. are active against a murine lymphoma cell line by inducing apoptosis and cell cycle arrest," Toxicology in Vitro, vol. 29, no. 7, pp. 1529-1536, 2015.

[63] A. Mira and K. Shimizu, "In vitro cytotoxic activities and molecular mechanisms of angelica shikokiana extract and its isolated compounds," Pharmacognosy Magazine, vol. 11, no. 44, p. 564, 2015.

[64] H. K. Abbas, B. B. Johnson, W. T. Shier, H. Tak, B. B. Jarvis, and C. D. Boyette, "Phytotoxicity and mammalian cytotoxicity of macrocyclic trichothecene mycotoxins from Myrothecium verrucaria," Phytochemistry, vol. 59, no. 3, pp. 309-313, 2002.

[65] K. E. von Milczewski, "Toxicity of epoxy trichothecenes in cultured mammalian cells," Mycotoxin Research, vol. 3, no. 2, pp. 69-76, 1987.

[66] M. Isaka, J. Punya, Y. Lertwerawat, M. Tanticharoen, and Y. Thebtaranonth, "Antimalarial activity of macrocyclic trichothecenes isolated from the fungus Myrothecium verrucaria," Journal of Natural Products, vol. 62, no. 2, pp. 329-331, 1999.

[67] T. Hayashi, T. Nakano, M. Kozuka, D. R. McPhail, A. T. McPhail, and K.-H. Lee, "Antitumor agents. 190.1 Absolute stereochemistry of the cytotoxic germacranolides, tomenphantins A and B, from Elephantopus tomentosus," Journal of Natural Products, vol. 62, no. 2, pp. 302-304, 1999.

[68] A. C. Beekman, H. J. Woerdenbag, W. Van Uden et al., "Structure-cytotoxicity relationships of some helenanolide-type sesquiterpene lactones," Journal of Natural Products, vol. 60, no. 3, pp. 252-257, 1997.

[69] V. M. Dirsch, A. M. Vollmar, and H. Stuppner, "Helenalin triggers a CD95 death receptor-independent apoptosis that is not affected by overexpression of Bcl-xL or Bcl-2," Cancer Research, vol. 61, no. 15, pp. 5817-5823, 2001.

[70] P. R. Huang, Y. M. Yeh, and T. C. V. Wang, "Potent inhibition of human telomerase by helenalin," Cancer Letters, vol. 227, no. 2, pp. 169-174, 2005. 
[71] K. M. Fernandes, C. A. Auld, R. G. Hopkins, and R. F. Morrison, "Helenalin-mediated post-transcriptional regulation of p21(Cip1) inhibits 3T3-L1 preadipocyte proliferation," Journal of Cellular Biochemistry, vol. 105, no. 3, pp. 913-921, 2008.

[72] P. E. Ordóñez, K. K. Sharma, L. M. Bystrom et al., "Dehydroleucodine, a sesquiterpene lactone from Gynoxys verrucosa, demonstrates cytotoxic activity against human leukemia cells," Journal of Natural Products, vol. 79, no. 4, pp. 691-696, 2016.

[73] A. Zahir, A. Jossang, B. Bodo, J. Provost, J.-P. Cosson, and T. Sévenet, "DNA topoisomerase I inhibitors: cytotoxic flavones from Lethedon tannaensis," Journal of Natural Products, vol. 59, no. 7, pp. 701-703, 1996.

[74] C. Y. Ragasa, D. L. Espineli, and C.-C. Shen, "Cytotoxic triterpene from Barringtonia asiatica," Pharmaceutical Chemistry Journal, vol. 48, no. 8, pp. 529-533, 2014.

[75] J.-J. Chen, S.-Y. Huang, C.-Y. Duh, I.-S. Chen, T.-C. Wang, and H.-Y. Fang, "A new cytotoxic amide from the stem wood of Hibiscus tiliaceus," Planta Medica, vol. 72, no. 10, pp. 935-938, 2006. 


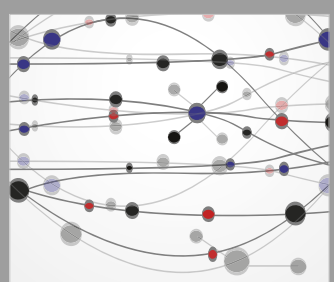

The Scientific World Journal
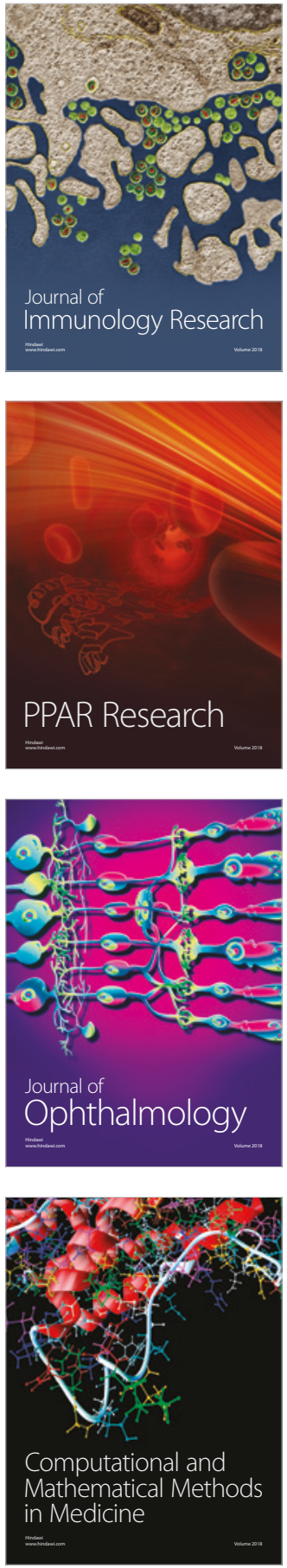

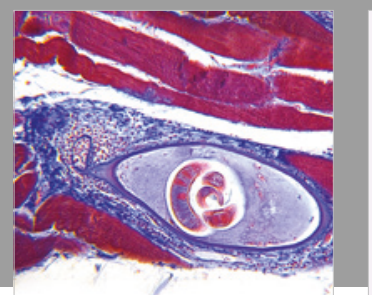

Gastroenterology Research and Practice

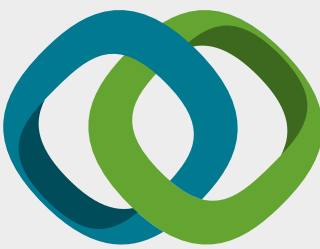

\section{Hindawi}

Submit your manuscripts at

www.hindawi.com
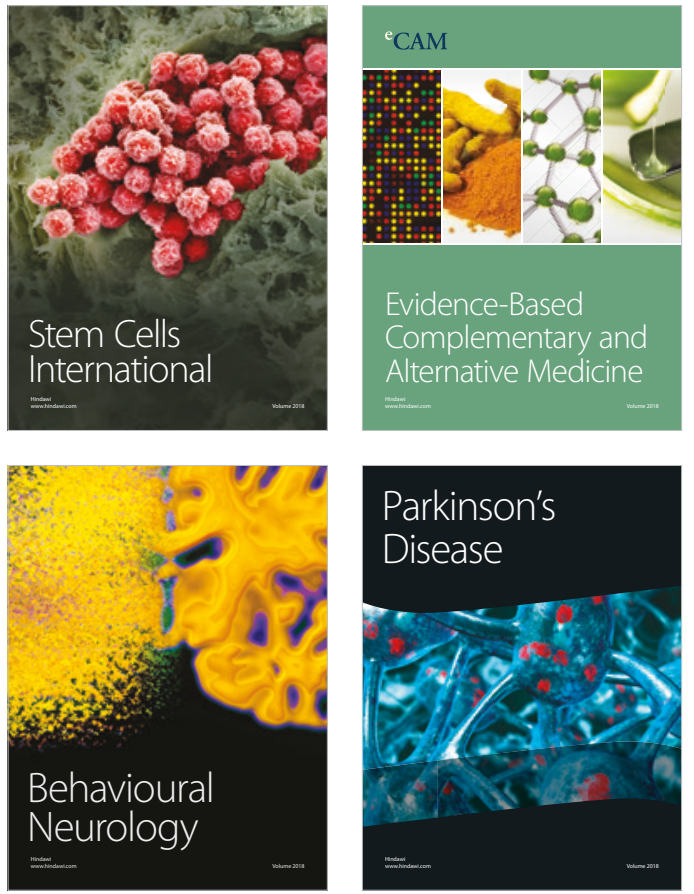

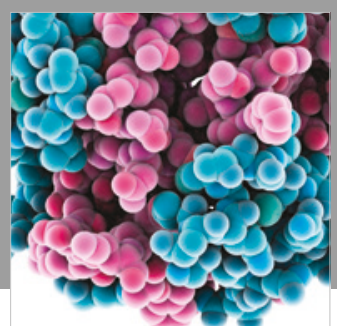

ournal of

Diabetes Research

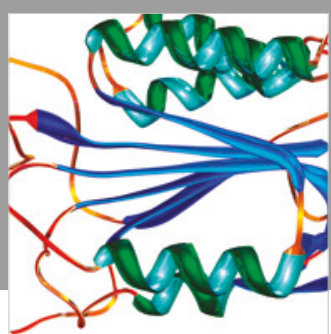

Disease Markers
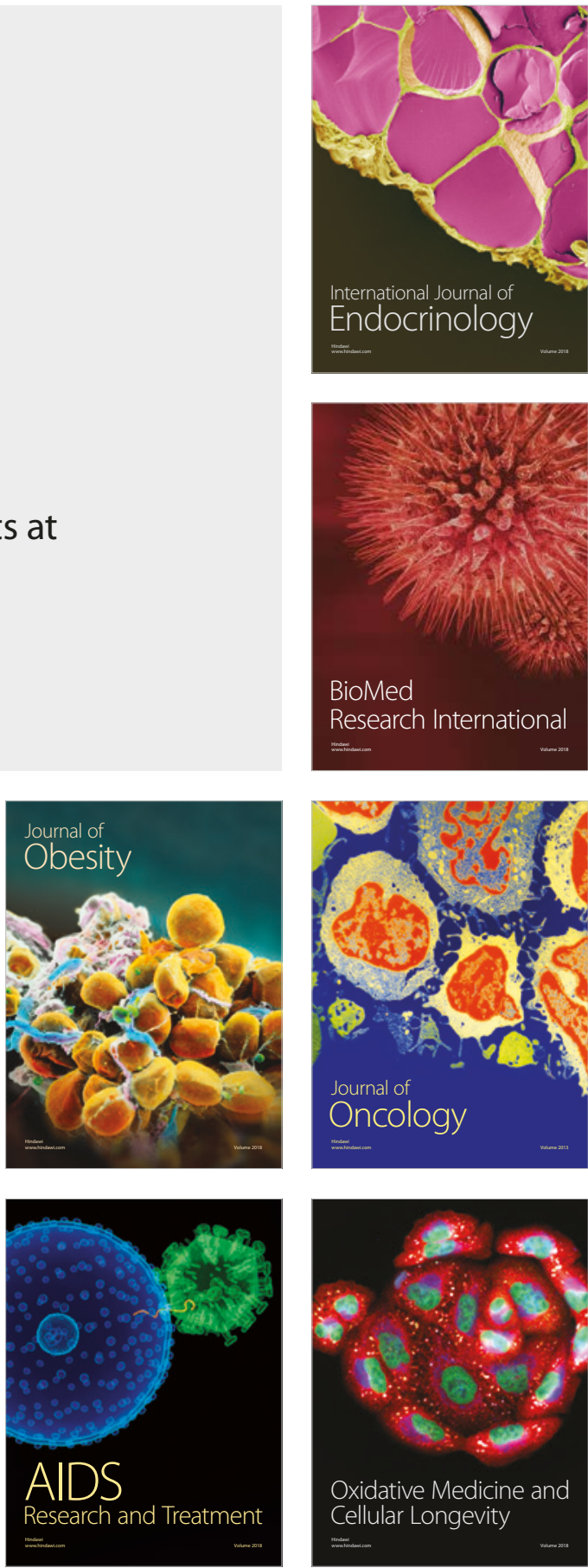